\title{
SYNTHESIS, CHARACTERIZATION AND PRELIMINARY CATALYTIC PROPERTIES OF NEW COPPER (I) COMPLEXE [Cu (pyrazolyl) $\left.)_{2}\right] X$ TYPE
}

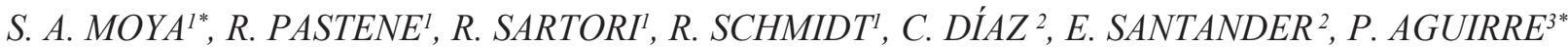 \\ A. J. PARDEY ${ }^{4}$, C. LONGO ${ }^{5}$, P. J. BARICELLI ${ }^{6}$. \\ ${ }^{1}$ Departamento de Química de los Materiales, Facultad de Química y Biología, \\ Universidad de Santiago de Chile, Santiago, Chile. \\ ${ }^{2}$ Departamento de Quimica, Facultad de Ciencias, Universidad de Tarapacá, Arica, Chile. \\ ${ }^{3}$ Facultad de Ciencias Químicas y Farmacológicas, Universidad de Chile. \\ ${ }^{4}$ Centro de Equilibrios en Solución, Escuela de Química, Facultad de Ciencias, Universidad Central de Venezuela, Caracas, Venezuela. \\ ${ }^{5}$ Centro de Investigación y Desarrollo de Radiofärmacos, Facultad de Farmacia, Universidad Central de Venezuela, Caracas, Venezuela. \\ ${ }^{6}$ Centro de Investigaciones Químicas, Facultad de Ingeniería, Universidad de Carabobo, Valencia, Venezuela.
}

(Received: October 19, 2009 - Accepted: December 29, 2009)

\begin{abstract}
The preparation of tetracoordinated copper (I) complexes with the pyrazolyl heterocyclic nitrogen ligand is reported. The new complexes of [Cu(pyrazolyl) $\left.{ }_{2}\right]$ $\mathrm{X}$ type with $\mathrm{X}=$ chloride, bromine, and iodine were characterized by spectroscopic and electrochemical techniques. The results obtained show that the heterocyclic nitrogen ligand is bonded in a bidentate fashion to form monometallic complexes. Exploratory homogeneous catalysis experiments of the water-gas shift reaction (WGSR) have been accomplished by the use of copper complexes in $80 \%$ aqueous 4-picoline solutions. For such systems, formation of $\mathrm{H}_{2}$ y $\mathrm{CO}_{2}$ was observed in the initial gas samples.
\end{abstract}

Keywords: Copper Complexes, Heterocyclic Nitrogen Ligand, Pyrazolyl Ligand, WGSR.

\section{INTRODUCTION}

Copper species are widely present in Nature as mono- or multinuclear metal complexes and play a crucial role in different enzymes and catalytic systems, leading to a currently growing interest in the development of new copper models ${ }^{1-2}$. In bioinorganic and organometallic chemistry the systems involving this metal represent one of the most relevant areas of investigation ${ }^{3}$.

Since Bruce and co-workers reported in 1972, the synthesis and characterization of the first carbonyl complex of copper(I) containing the ligand tris(pyrazolyl)borate, $\left[\mathrm{HB}(\mathrm{Pz})_{3}\right] \mathrm{CuCO}(\mathrm{Pz}=$ pyrazolyl ring), the development of complex chemistry of ligands containing pyrazolyl experienced a significant development ${ }^{4,5}$. A driving force for much of the chemistry in this area stems from its biological relevance as structural probes for oxygen-binding enzymes and from the importance of this kind of compounds in organometallic catalysis $^{6-9}$.

The catalytic behavior of a compound can be strongly influenced by the type of ligands. Moreover, the use of suitable substituents may increase the catalytic performance of certain systems. In the chemistry of copper (I) with derivatives of pyrazolyl, most studies do not incorporate the analysis of the effects of the substituents of the ligands or the variation of the ligands attached directly to copper (I). Interestingly Dias et al., reported the synthesis and characterization of tris (pyrazolyl) borate ligands containing six $\mathrm{CF}_{3}$ substituents and showed the effects of electron-withdrawing $\mathrm{CF}_{3}$ groups on the structure and spectroscopic properties of $\left[\mathrm{HB}\left(3.5-\left(\mathrm{CF}_{3}\right)_{2} \mathrm{Pz}\right)_{3}\right] \mathrm{CuCO}^{10}$

Since little has been done to study the effect of electron-withdrawing ligands on the catalytic behavior of copper(I) complexes containing pyrazolyl ligands ${ }^{11}$, we have carried out the synthesis, characterization, electrochemistry and preliminary determination of the catalytic properties of a series of new copper(I) complexes of the type $\left[\mathrm{Cu}(\text { pyrazolyl) })_{2}\right] \mathrm{X}$, with $\mathrm{X}=$ chloride, bromine, or iodine. The structure of the $\left[\mathrm{Cu}(\text { pyrazolyl })_{2}\right] \mathrm{Cl}$ complex is shown in Figure 1.

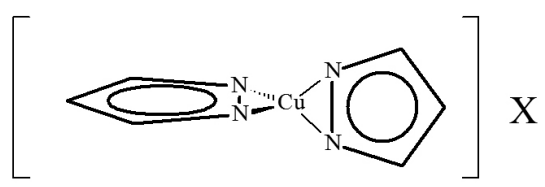

$\mathrm{X}=\mathrm{Cl}, \mathrm{Br}, \mathrm{I}$

Figure 1. Schematic drawing of the copper complex.

\section{EXPERIMENTAL}

\section{Physical Measurements}

IR spectra were obtained in a Bruker IFS-66 V FT-IR spectrophotometer in $\mathrm{KBr}$ disks and $\mathrm{CHCl}_{3}$ solutions. Proton NMR spectra were recorded on a Bruker DPX 200 (operating at $200.131 \mathrm{MHz}$ ) spectrometer using deuterated solvents at $25 \pm 5{ }^{\circ} \mathrm{C}$. Absorption spectra were measured on a Shimadzu UV-160 spectrophotometer using different solvents (in $0.5 \times 10^{-3}-1 \times 10^{-4}$ mol $\mathrm{dm}^{-3}$ solutions) in quartz cells. Molar extinction coefficients were calculated from a least-square linear regression of absorbance data at different concentrations. Microanalyses were performed by Laboratoire d'Analyses du CNRS, Villeurbanne (France) and the copper determination was made in an absorption atomic spectrometer Perkin Elmer 2380. Molar conductivities were determined in $\mathrm{CHCl}_{3}$ at $25{ }^{\circ} \mathrm{C}$ using a conductivity meter Cole-Parmer 01481 . Electrochemical measurements were carried out on a classical three-electrode potentiostatic setup consisting of a Bank-Wenking POS 73 potentiostat and a XY Graphtec WX 4301 recorder. Working and auxiliary electrodes were a modified Pt flat disk electrode and a Pt wire, respectively. The reference electrode aqueous saturated sodium chloride calomel (SCE) was connected to the electrolysis cell by a Vycor bridge filled with anhydrous solvent and support electrolyte. The solutions were $10^{-4} \mathrm{~mol} \mathrm{dm}^{-3}$ in copper complex and $0.1 \mathrm{~mol} \mathrm{dm}^{-3}$ in tetrabutylammonium perchlorate (TBAP) and all of them were deaerated with nitrogen. Coulometry experiments were carried out using a Bank-Wenking potentiostat (model POS 73) connected to an integrator (model CIDE 93). Gas sample analyses from catalytic runs were performed on a Hewlett-Packard 5890 Series II programmable gas chromatograph fitted with Carbosieve-B (mesh 80-100) column and thermal conductivity detector. Analyses of liquid phase reaction products were done on a Hewlett-Packard 5890 Series II programmable gas chromatograph fitted with $3 \%$ OV-10N Supelcoport (mesh 80-100) column and flame ionization detector using ortoxilene as an internal standard, and identified by co-injection on a HewlettPackard 5890 Series II programmable gas chromatograph-mass spectrometer fitted with a capillary column $(50 \mathrm{~m})$.

\section{Procedures}

Redox potentials were quoted vs. ferrocenium/ferrocene couple $\left(\mathrm{Fc}^{+}\right.$ $\mathrm{Fc}, \mathrm{E}_{1 / 2}=+0.380 \mathrm{~V}$ versus $\mathrm{SCE}$ ) recorded to the maximum peaks of the cyclic voltammograms at $22{ }^{\circ} \mathrm{C}$ of constant temperature. The nitrogen used for purging was purified by passage through a tube with Drierite $\left(\mathrm{CaSO}_{4}\right.$ anhydrous, Aldrich). A sweep rate of $200 \mathrm{mV} \mathrm{s}^{-1}$ was used for all the scans. Potentials were reported as $E_{1 / 2}=1 / 2\left(E p_{a}+E p_{c}\right)$, where $E p_{a}$ and $E p_{c}$ were the anodic and cathodic peak potentials, respectively. Ferrocene was used as an internal standard to compensate the junction potential variability 
among experiments. WGSR catalyst test was performed under batch reaction conditions ${ }^{12}$. In a typical catalyst WGSR experiment, a given amount of the copper complex was dissolved in $10 \mathrm{~mL}$ of 4-picoline/water, 8/2, v/v and placed in a reactor flask fitted with a Teflon stopcock plus a ground-glass joint for attachment to a vacuum line equipped with a manometer and gas inlet. The solution was degassed by three freeze-pump-thaw cycles. The flask was charged at the pressure of $0.9 \mathrm{~atm}$ with the $\mathrm{CO} / \mathrm{CH}_{4}(94 / 6 \%)$ mixture $\left(\mathrm{CH}_{4}\right.$ was present as an internal standard). The reactor vessel was stirred magnetically in a thermostated glycerine bath $\left(100 \pm 0.5^{\circ} \mathrm{C}\right)$ for $4-6$ hours. Gas samples of $1.0 \mathrm{~mL}$ were periodically removed from the reaction vessel at bath temperature with Pressure Lok syringes (Precision Sampling Corporation), analyzed by gas chromatography and corrected for small background signals. The reaction vessel was flushed at the end of heating time and then recharged with $\mathrm{CO} / \mathrm{CH}_{4}$ in a manner similar to that used for the initiation of the run. Darkening of the solutions always occurred during the first 15 minutes of a WGSR run.

\section{Materials}

Solvents and chemicals were reagent grade and purified according to a described procedure ${ }^{13}$. Pyrazole (Merck), $\mathrm{CuBr}$ and $\mathrm{CuCl}$ (Fluka), and $\mathrm{CuI}$ (Merck) were commercially available and used without purification.

\section{Synthesis of copper complexes}

The copper (I) complexes were prepared according to the general onestep procedure developed for us: The heterocyclic nitrogen ligand solution in methanol was added to a suspension of copper (I) halide in methanol in the metal/ligand ratio 1:2. The suspension was stirred under reflux for 24 hours. The resulting solids were isolated by filtration. The products were washed with methanol and dried at room temperature to give (1) - (3). Chloroform or nitromethane can also be used as reaction solvents.

ICu(pyrazolyl) ${ }_{2} / C l$ (1). IR, $v_{\mathrm{C}-\mathrm{N}}$ ( $\mathrm{KBr}$ disk): 1630 (broad), 1521(m), $1474(\mathrm{~m}), 1405(\mathrm{~m}) \mathrm{cm}^{-1}$. UV/Vis (MeCN): $670\left(\varepsilon=224 \mathrm{dm}^{3} \mathrm{~mol}^{-1} \mathrm{~cm}^{-1}\right)$. Anal. calcd. for $\mathrm{Cu}(\mathrm{Cl})\left(\mathrm{C}_{3} \mathrm{H}_{2} \mathrm{~N}_{2}\right): \mathrm{C}, 30.65 ; \mathrm{H}, 3.43: \mathrm{N}, 23.83 ; \mathrm{Cu}, 27.02 \%$. Found C, $31.05 ; \mathrm{H}, 3.20 ; \mathrm{N}, 25.02 ; \mathrm{Cu} 27.80 \%$. Molar conductivity (ethanol) $32 \mathrm{ohm}$ ${ }^{1} \mathrm{~cm}^{2} \mathrm{~mol}^{-1}$. Melting point, $240{ }^{\circ} \mathrm{C}(\mathrm{d})$. Yield $90 \%$.

$\boldsymbol{C u}(\boldsymbol{B r})\left(\right.$ pyrazolyl) $/ \mathbf{I}$ (2). IR, $v_{\mathrm{C}=\mathrm{N}}(\mathrm{KBr}$ disk): 1634 (broad), 1513(m), 1489(m), $1406(\mathrm{~m}) \mathrm{cm}^{-1}$. UV/Vis $(\mathrm{MeCN}): 672\left(\varepsilon=1073 \mathrm{dm}^{3} \mathrm{~mol}^{-1} \mathrm{~cm}^{-1}\right)$. Anal. calcd. for $\mathrm{Cu}(\mathrm{Br})\left(\mathrm{C}_{3} \mathrm{H}_{4} \mathrm{~N}_{2}\right)$ : C, 25.78; H, 2.89; N, 22.73; $\mathrm{Cu}, 22.73 \%$. Found: $\mathrm{C}, 26.07 ; \mathrm{H}, 3.11 ; \mathrm{N}, 21.91 ; \mathrm{Cu}, 21.67 \%$. Molar conductivity (ethanol) $19 \mathrm{ohm}^{-1} \mathrm{~cm}^{2} \mathrm{~mol}^{-1}$. Melting point, $248{ }^{\circ} \mathrm{C}(\mathrm{d})$. Yield $95 \%$.

Cu(I)(pyrazolyl) 2 II (3). IR, $v_{\mathrm{C}=\mathrm{N}}(\mathrm{KBr}$ disk): 1621 (broad), $1522(\mathrm{~m})$, $1489(\mathrm{~m}), 1407(\mathrm{~m}) \mathrm{cm}^{-1}$. UV/Vis $(\mathrm{MeCN}): 410(\mathrm{sh})$. Anal. calcd. for $\mathrm{Cu}(\mathrm{I})$ $\left(\mathrm{C}_{3} \mathrm{H}_{4} \mathrm{~N}_{2}\right)_{2}: \mathrm{C}, 22.06 ; \mathrm{H}, 2.47 ; \mathrm{N}, 17.16 ; \mathrm{Cu}, 19.44 \%$. Found: $\mathrm{C}, 22.55 ; \mathrm{H}$, $2.96 ; \mathrm{N}, 18.13 ; \mathrm{Cu}, 18.92 \%$. Molar conductivity (ethanol) $15 \mathrm{ohm}^{-1} \mathrm{~cm}^{2} \mathrm{~mol}^{-1}$. Melting point, $>250{ }^{\circ} \mathrm{C}$. Yield $94 \%$.

\section{RESULT AND DISCUSSION}

The preparative methods produce air stable compounds in good yields. The three complexes show moderate solubility in methanol. The solubility improves in ethanol, chloroform and nitromethane, which can be also used as solvents for the reaction.

The purity of the compounds was confirmed by elemental analysis. The agreement between the values obtained experimentally and those calculated for the specific formulas for the complexes give support to the proposed structure for them.

The conductivities obtained indicate that these compounds behave as 1:1 electrolytes in ethanol solutions, which supports the suggested constitution of these systems as a copper metal surrounded by the pyrazolyl ligands in the first coordination sphere and the halide located as a counter-ion.

\section{Spectroscopical and Electrochemical Properties}

IR spectra of the three copper-pyrazolyl complexes show three medium and one wide stretching bands in the region of $v_{\mathrm{C}=\mathrm{N}}$ which is a good indication that the pyrazolyl group coordinates as a bidentate ligand ${ }^{14}$. These bands appear in the region $1650-1400 \mathrm{~cm}^{-1}$ and are very similar to those observed in the uncoordinated nitrogen ligand, clearly indicating the coordination of the pyrazolyl nitrogen atoms to the metal. Figure 2 shows, for the case of the chlorinated complex, a broad band at $1630 \mathrm{~cm}^{-1}$ and three bands of medium intensity at 1521,1474 and $1405 \mathrm{~cm}^{-1}$. These bands appear slightly displaced from those similar that shows the uncoordinated pyrazol. This shift is the consequence of the coordination produced.

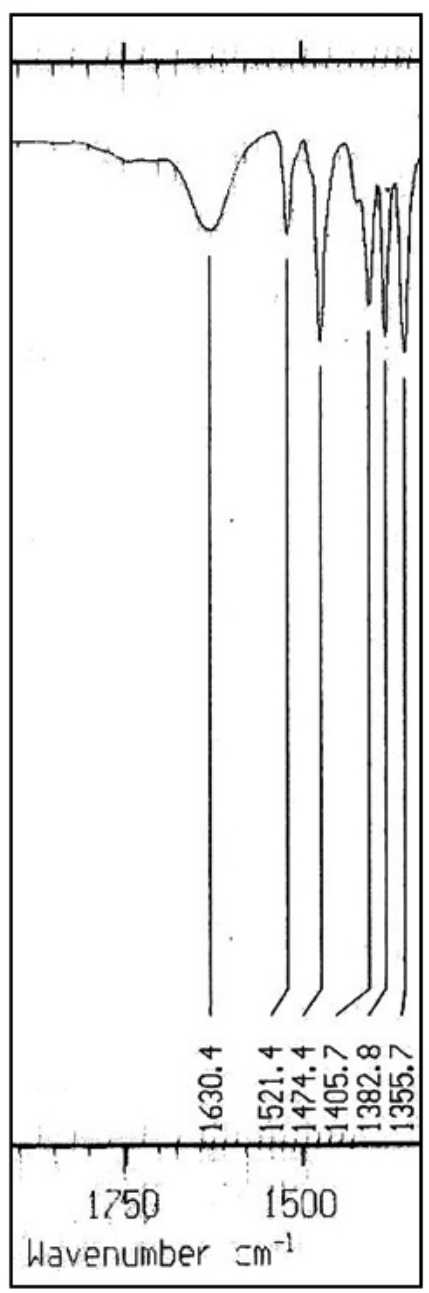

Figure 2. Infrared spectral region that shows the bands of $v_{\mathrm{C}=\mathrm{N}}$ stretching corresponding to the pyrazolyl ligand of the complex $\left[\mathrm{Cu}(\text { pyrazolyl })_{2}\right] \mathrm{Cl}$.

Electronic spectra in several solvents for these complexes show essentially three bands. Two appear at very high energy and they are assigned as intraligand transitions due to the similar shape, position and intensity when they are compared with the absorption spectrum of the free nitrogen ligand. The third band, which is the lowest energy absorption band, when registered in $\mathrm{MeCN}$, appears at $670 \mathrm{~nm}$. The intensity of this band is low $\left(\varepsilon=224 \mathrm{dm}^{3} \mathrm{~mol}^{-1}\right.$ $\left.\mathrm{cm}^{-1}\right)$. This band might be thought to correspond to a $d-d$ band, which rules out the presence of a $d^{10}$ system for a copper(I); Moreover, when the electronic spectrum is recorded in solvents of different polarities, this band undergoes a bathochromic shift. These considerations support the assignation of this band as metal-to-ligand charge transfer (MLCT), from filled $d$ orbitals of the $\mathrm{Cu}(\mathrm{I})$ centers ( $d^{I 0}$ configuration) to the unoccupied $\pi^{*}$ orbital of the heterocyclic nitrogen ligand) $)^{15}$.

Furthermore, the ${ }^{1} \mathrm{H}-\mathrm{NMR}$ spectra show the typical proton signals associated to the pyrazolyl ligand coordinated to the copper atom (Figure 3 ). The H-NMR spectra for the coordinated ligand shows two signals corresponding to the protons $\mathrm{Ha}, \mathrm{Hb}$ and $\mathrm{Hc}$. Ha-Hc protons appear in the spectrum, at similar field and there is no significant displacement of the signals by coordination effect. $\mathrm{Hb}$ signal appears at lower field relative to the uncoordinated ligand. In none of the compounds, the $\mathrm{NH}$ signal was observed, which disappears as a result of the coordination, which supports the proposed structure of the synthesized compounds. 


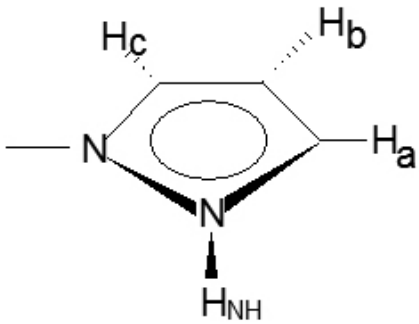

Figure 3. Structure of the pyrazolyl ligand showing the hydrogen labelling.

Table 1. Proton NMR data for the ligand and complexes a .

\begin{tabular}{|cccc|}
\hline Compound & $\mathrm{H}_{\mathrm{a}, \mathrm{c}} \mathrm{H}_{\mathrm{c}}$ & $\mathrm{H}_{\mathrm{b}}$ & $\mathrm{H}_{\mathrm{NH}}$ \\
\hline Pyrazolyl & $7.55(\mathrm{~m})$ & $6.25(\mathrm{~m})$ & $20.0(\mathrm{~s})$ \\
1. $\left[\mathrm{Cu}(\text { pyrazolyl })_{2}\right] \mathrm{Cl}$ & $7.54(\mathrm{~m})$ & $5.50(\mathrm{~m})$ & \\
2. $\left[\mathrm{Cu}(\text { pyrazolyl })_{2}\right] \mathrm{Br}$ & $7.34(\mathrm{~m}))$ & $5.25(\mathrm{~m})$ & \\
3. $\left[\mathrm{Cu}(\text { pyrazolyl })_{2}\right] \mathrm{I}$ & $7.19(\mathrm{~m})$ & $5.30(\mathrm{~m})$ & \\
\hline
\end{tabular}

${ }^{\text {a }}$ Signal labels refer to fig. 3 ; $\mathrm{d}$ in ppm with TMS as reference in $\mathrm{CDCl}_{3}$ at room temperature at $200.131 \mathrm{MHz}$.

Redox potentials of the copper halides, listed in the table 2, were determined by cyclic voltammetry in acetonitrile solutions using TBAP as supporting electrolyte and measured against the ferrocenium / ferrocene couple $\left(\mathrm{Fc}^{+} / \mathrm{Fc}\right)$. Quasi-reversibility approaches here observed by looking at the difference of potential between anodic peak and cathodic peak $(\Delta \mathrm{Ep})$, the ratio between the intensities of anodic and cathodic peaks (ip / ip » 1) and the relationship between the current and sweep rate. Relationship between the average intensity vs $v^{1 / 2}$ was used to determine if the processes of electronic transfer of these complexes were controlled by diffusion. In cyclic voltammetry all the complexes exhibit one reduction and two oxidation peaks in the range- 2.4 to 1.6 volts $\mathrm{vs} \mathrm{Fc}^{+} / \mathrm{Fc}$ in acetonitrile solutions at $200 \mathrm{mV} \mathrm{s}^{-1}$.

Table 2. Electrochemical Data for the Copper halides Complexes.

\begin{tabular}{|c|c|c|c|c|}
\hline \multirow{2}{*}{ Complex } & \multicolumn{4}{|c|}{ Redox Potential a, $\mathrm{V}$} \\
\hline & & $\mathrm{E}_{\text {reduction }}$ & \multicolumn{2}{|c|}{$\mathrm{E}_{\text {oxidation }}$} \\
\hline 1. $\left[\mathrm{Cu}(\text { pyrazolyl })_{2}\right] \mathrm{Cl}$ & $\begin{array}{l}E p_{c} \\
E p_{a} \\
E p_{1 / 2} \\
E p^{c}\end{array}$ & $\begin{array}{c}-0.490^{\mathrm{b}} \\
- \\
\text { (i) } \\
-\end{array}$ & $\begin{array}{c}+0.090 \\
-0.155 \\
-0.123 \\
245\end{array}$ & $\begin{array}{c}+0.670^{\mathrm{b}} \\
- \\
\text { (i) } \\
-\end{array}$ \\
\hline 2. $\left[\mathrm{Cu}(\text { pyrazolyl })_{2}\right] \mathrm{Br}$ & $\begin{array}{l}E p_{c} \\
E p_{a} \\
E p_{1 / 2} \\
E p^{c}\end{array}$ & $\begin{array}{c}-1.065^{b} \\
- \\
\text { (i) } \\
-\end{array}$ & $\begin{array}{c}+0.155 \\
-0.075 \\
+0.115 \\
230\end{array}$ & $\begin{array}{c}+0.615 \\
+0.395 \\
+0.505 \\
220\end{array}$ \\
\hline 3. $\left[\mathrm{Cu}(\text { pyrazolyl })_{2}\right] \mathrm{I}$ & $\begin{array}{l}\mathrm{Ep}_{\mathrm{c}} \\
\mathrm{Ep}_{\mathrm{a}} \\
\mathrm{Ep}_{1 / 2} \\
\mathrm{Ep}^{\mathrm{c}}\end{array}$ & $\begin{array}{c}-0.355^{\mathrm{b}} \\
- \\
\text { (i) } \\
-\end{array}$ & $\begin{array}{c}+0.006 \\
-0.489 \\
-0.248 \\
495\end{array}$ & $\begin{array}{c}+0.333 \\
+0.209 \\
+0.271 \\
124\end{array}$ \\
\hline$\left(\mathrm{Fc}^{+} / \mathrm{Fc}\right)$ & $\begin{array}{l}E p_{c} \\
E p_{a} \\
E p_{1 / 2} \\
E p^{c}\end{array}$ & & $\begin{array}{c}+0.420 \\
+0.340 \\
+0.380 \\
80\end{array}$ & \\
\hline
\end{tabular}

${ }^{a}$ Redox potentials in volts vs $\mathrm{Fc}^{+} / \mathrm{Fc}$ in acetonitrile solutions $\left(10^{-4} \mathrm{~mol} \mathrm{dm}^{-}\right.$ $\left.{ }^{3}\right)$, using TBAP $\left(10^{-1} \mathrm{~mol} \mathrm{dm}^{-3}\right)$ as supporting electrolyte at a scan rate $=200$ $\mathrm{mV} \mathrm{s}^{-1} ;{ }^{\mathrm{b}}$ irreversible; ${ }^{\mathrm{c}} \mathrm{DEp}=\mathrm{Ep}_{\mathrm{c}}-\mathrm{Ep}_{\mathrm{a}}$ in $\mathrm{mV}$.

The reduction wave could be assigned to a reversible reduction centred in the heterocyclic nitrogen ligand. The three copper complexes presented two quasi-reversible oxidation waves in the region 0.0 to +1.6 volts $\mathrm{vs}^{\mathrm{F}} \mathrm{Fe}^{+}$ $\mathrm{Fc}$. The first peak is attributable to the $[\mathrm{Cu} \text { (pyrazolyl) }]^{+/ 0}$ one-electron process; this wave was assigned to a monoelectronic oxidation process centred at the metal atom corresponding to the $\mathrm{Cu}(\mathrm{I}) / \mathrm{Cu}(\mathrm{II})$ redox couple ${ }^{16}$. Figure 4 shows the cyclic voltammogram for the oxidation waves of the $\left[\mathrm{Cu}(\text { pyrazolyl })_{2}\right] \mathrm{Br}$ complex. The most positive oxidation peak is difficult to assign to a given process, due to the quasi-reversibility of the initial oxidation.
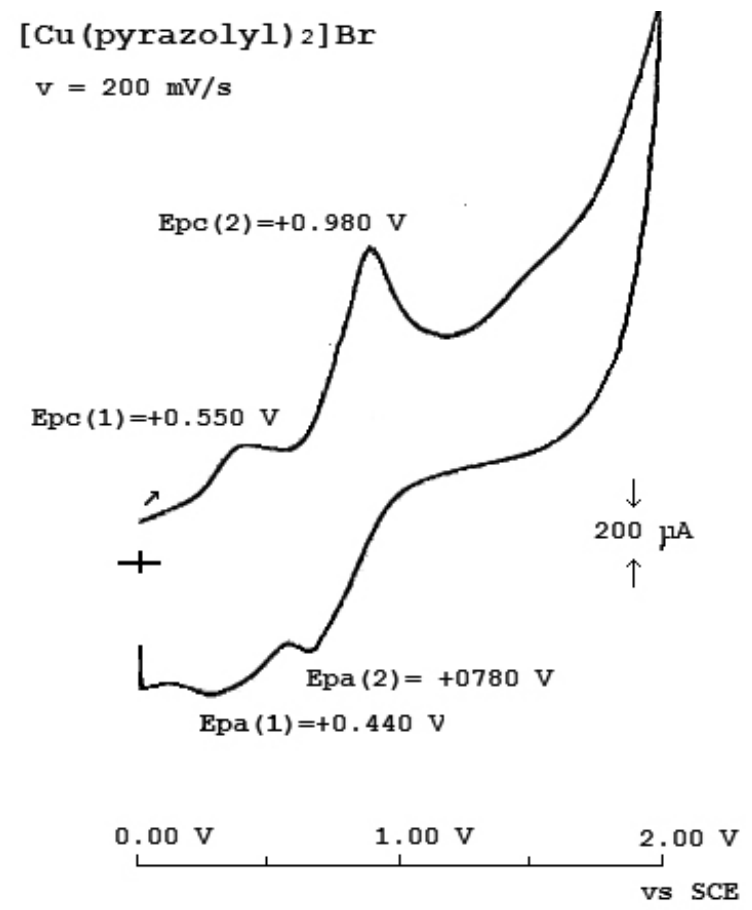

Figure 4. Cyclic voltammmogram for $\left[\mathrm{Cu}(\text { pyrazolyl) })_{2}\right] \mathrm{Br}$ in acetonitrile solution with $0.1 \mathrm{~mol} \mathrm{dm}^{-3}$ of TBAP, $v=200 \mathrm{mV} \mathrm{s}^{-1}$ in the range 0.0 to $2.0 \mathrm{~V}$ versus SCE.

\section{Catalytic studies}

The copper $\left[\mathrm{Cu}(\text { pyrazolyl) })_{2}\right] \mathrm{X}(\mathrm{X}=\mathrm{Cl}, \mathrm{Br}$ or I) complexes form a system which shows catalytic activity for the water gas shift reaction ${ }^{15}\left(\mathrm{CO}+\mathrm{H}_{2} \mathrm{O}\right.$ $\rightleftharpoons \mathrm{CO}_{2}+\mathrm{H}_{2}$, WGSR, eq.[1]) under $\mathrm{P}(\mathrm{CO})=0.9 \mathrm{~atm}$ at $100{ }^{\circ} \mathrm{C}$, in $10 \mathrm{~mL}$ of $80 \%$ aqueous 4-picoline as a base. For such systems, formation of $\mathrm{H}_{2}$ and $\mathrm{CO}_{2}$ was observed in the initial gas samples taken soon after the reaction solution reached operation temperature. In each case a $1: 1 \mathrm{H}_{2} / \mathrm{CO}_{2}$ ratio was observed as required by equation [1]. The data obtained from these studies show that $\operatorname{TF}\left(\mathrm{H}_{2}\right)$ values do not depend on the nature of the coordinated halogen. Although these systems are stable they are low active catalysts in comparison to the homogeneous WGSR catalytic $\mathrm{Cu} / \mathrm{amine}$ system (amine = 4-picoline, 3-picoline, 2-picoline, pyridine, 3,5-lutidine or 2,6-lutidine) previously reported ${ }^{17}$. We have also investigated the versatility of these copper complexes in the conversion of organic substrates under the WGSR conditions ${ }^{18}$. Table 3 shows the catalytic activity of the copper complexes in the WGSR. From this information, it is possible to conclude that these compounds generate stochiometric rather than catalytic systems, since for each metal atom a mol of hydrogen is generated $(\mathrm{TF}=1)$. In addition, these copper complexes do not convert nitrobenzene to aniline ${ }^{19}$ at $\mathrm{P}(\mathrm{CO})=0.9 \mathrm{~atm}, \mathrm{~T}=100^{\circ} \mathrm{C}$, in $10 \mathrm{~mL}$ of $80 \%$ aqueous 4-picoline.

Table 3. Catalytic Activity of $\left[\mathrm{Cu}(\text { pyrazolyl })_{2}\right] \mathrm{X}$ in the WGSR ${ }^{\mathrm{a}} .0$.

\begin{tabular}{|c|c|c|c|}
\hline $\mathrm{X}$ & {$[\mathrm{Cu}](\mathbf{m M})$} & $\mathbf{T F}\left(\mathrm{CO}_{2}\right)^{{ }^{\mathrm{b}}}$ & $\mathbf{T F}\left(\mathrm{H}_{2}\right)^{\mathbf{b}}$ \\
\hline $\mathrm{Cl}$ & 10 & 1.0 & 1.0 \\
\hline $\mathrm{Br}$ & 10 & 1.0 & 1.0 \\
\hline $\mathrm{I}$ & 10 & 1.0 & 1.0 \\
\hline
\end{tabular}

a $8 \mathrm{~mL}$ of 4-picoline, $2 \mathrm{~mL}$ of $\mathrm{H}_{2} \mathrm{O}, \mathrm{P}(\mathrm{CO})=0.9$ atm at $100{ }^{\circ} \mathrm{C}$.

${ }^{\mathrm{b}} \mathrm{TF}($ gas $)=\operatorname{mol}$ gas $(\mathrm{mol} \text { complex } * \text { day })^{-1}$. 


\section{ACKNOWLEDGEMENTS}

This work was supported by FONDECYT-CHILE (project 1085135).

\section{REFERENCES}

1.- E. I. Solomon; U. M. Sundaram, T. E. Machonkin, Chem. Rev., 1996. 96, 2563.

2.- S. Trofimenko, Chem. Rev.,1993, 93, 943.

3.- E. Kim; E. E. Chufan; K. Kamarai; K. D. Karlin, Chem. Rev., 2004,104, 1077.

4.- M. I. Bruce; A. P. P. Ostazewski, J. Chem. Soc., Chem. Commun. 1972, 1124.

5.- M. R. Churchill; B. G. De Boer; F. J. Rotella; O. M. A. Salah; M. I. Bruce, Inorg. Chem. 1975, 14, 2051; Claudio Pettinari; F. Marchetti; C. Santini; R. Pettinari; A. Drozdov; S. Troyanov; G. A. Battiston; R.Gerbasi, Inorganica Chim. Acta, 2001, 315, 88.

6.- J. O. Alben; P. P. Moh; F. G. Fiamingo; R. A. Altschuld, PROCEDURES Natl. ACAD. Sci. USA 1981, 78,234.

7.- 1. Y. Fager, J. O. Alben, Biochemistry 1972, 11, 4786.

8.- a) E. I. Solomon; P. M. Jones; J. A. Maj, Chem. Rev. 1993, 93, 2623. b) K. Fujisawa; T. Ono; H. Aoki; Y. Ishikawa; Y. Miyashita; K. Okamoto; H. Higashimura, Inor. Chem. Comm. 2004, 7, 330.c) J. Gao, J. H. Reibenspies and A. E. Martell, Inorg. Chim. Acta 2002,157, 338. d) D. L. Reger; J. E. Collins, Organometallic, 1996, 15, 2029. e) L. Wang; J. C. Cambrón; E. Espinosa, New J. Chem., 2009, 33, 327. f) Y. H. Xing; X. J. Zhang; Z. Sun;
J. Hana; Y. H. Zhang; B. L. Zhang; M. F. Ge; S. Y. Niu, Spectrochimica Acta Part A 2007, 68, 1256. g) M. E. Moret; P. Chen, Organometallics 2008, 27, 4903.

9.- C. Pettinari, F. Marchetti, C. Santini, R. Pettinari, A. Drozdov, S. Troyanov, G. A. Battiston, R. Gerbasi, Inorg. Chim. Acta, 2001, 88, 315. 10.- H. V. Rasika Dias; H. Lu, Inorg. Chem., 1995, 34, 5380.

11.- G. Agrifoglio, Inorg. Chim. Acta, 1992, 197,159; U. E. Bucher; A. Currao; R. Nesper; H. Ruegger;L. M. Venanzi; E. Younger, Inorg. Chem., 1995,34,66.

12.- C. Ungermann, V. Landis, S. A. Moya, H. Cohen,H. Walker, R. G. Pearson, R. G. Rinker, P. C. Ford, J. of Am. Chem. Soc, 1979, 5922. b) A. J. Pardey, M.A. Moreno, M. C. Ortega, B. Mendez, A. B. Rivas, S. A. Moya, D. Villagra, M. Lutz, J. of Chil. Chem. Soc. 2003, 48, 19.

13.- A I. Gordon; R. A. Ford; The Chemist's Companion, J. Wiley \& Sons, Inc., N.Y. 1972.

14.- M. A. Masood, D. J. Hodgson, Inorg. Chem. 1993, 32, 4839.

15.- C. Piguet; G. Bernardinelli; A. F. Williams, Inorg. Chem., 1989, 28, 2920.

16.- M. A. Masood; P. S. Zacharias, J. Chem. Soc. Dalton Trans. 1991, 111.

17.- A. J. Pardey; M. Fernández; M. A. Moreno; J. Alvarez; B. Mendez, A. B. Rivas; M. C. Ortega; P. Baricelli; C. Longo, React. Kinet. Catal. Lett. 2000, 70, 293.

18.- D. Escaffre; A. Thorey; P. Kalck, J. Mol. Catal. 1985, 33, 87.

19.- C. Longo; J. Alvarez; M. Fernandez; A. J. Pardey; S. A. Moya; P. Baricelli; M. Mdleleni, Polyhedron, 2000, 19, 487. 